\title{
A supplementary description of Brisaster iheringi (Spatangoida: Schizasteridae) from the Miocene of Patagonia Argentina
}

\author{
Sergio Martínez ${ }^{1 *} \&$ Claudia J. del Río ${ }^{2}$ \\ 1. Universidad de la República, Facultad de Ciencias, Departamento de Paleontología, Iguá 4225, 11400 Montevideo, \\ Uruguay; smart@fcien.edu.uy \\ 2. Museo Argentino de Ciencias Naturales "B. Rivadavia”, A. Gallardo 470, C1405DJR Buenos Aires, Argentina; \\ claudiajdelrio@gmail.com
}

Received 15-XII-2016. Corrected 03-IV-2017. Accepted 07-VI-2017.

\begin{abstract}
Neogene Argentinean echinoids are important biostratigraphic tools. New specimens of Schizaster iheringi (de Loriol, 1902) from Early Miocene sedimentites (Chenque Formation, Patagonia, Argentina) allowed us to improve its original description, providing for the first time details of the apical disc and the oral side of test. The species is included into the genus Brisaster: the first unquestionable documented reference to the taxon from the Neogene of Argentina. All previously reported specimens of this species are evaluated, concluding that the stratigraphic range of the genus Brisaster in Patagonia must be restricted to the Early Miocene. Rev. Biol. Trop. 65(Suppl. 1): S137-S146. Epub 2017 November 01.
\end{abstract}

Key words: Argentina; Miocene; Chenque Fm.; Spatangoida; Brisaster.

True diversity of fossil echinoids in the Neogene of Southern South America is still unknown. Although several studies involving Argentinean sand dollars have been recently performed bringing into light many new species (Martínez, 1984; Mooi, Martínez \& Parma, 2000; Martínez \& Mooi, 2005; Martínez, Reichler \& Mooi, 2005; Kroh, Mooi, del Río \& Neumann, 2013; Mooi, Martínez \& del Río, 2016), the knowledge of other groups -like spatangoids- is incipient. Besides, with the exception of Parma (2012), who includes Neogene findings of Brissopsis L. Agassiz, 1840 , most part of the studies are focused on Paleocene associations (Parma \& Casadío, 2005; del Río, Stilwell, Martínez \& Concheyro, 2007; Martínez, del Río \& Concheyro, 2011).

As happens with other Neogene Argentinean echinoids, it is very important to clarify the status of the different species, since some of them have been extensively used as biostratigraphic tools, but with inferences obscured because of poor taxonomical knowledge. Examples of this situation are the confusion generated by Ortmann (1902), who misidentified Schizaser ameghinoi Ihering, 1897 with $S$. iheringi de Loriol (1902), or the inclusion into Iheringiella Berg, 1898 of every sand dollar without a lunule, or into Monophoraster Lambert \& Thiéry, 1921 when having one, an attractive but simplistic dichotomy (see Mooi, Martínez \& Parma, 2000; Martínez, Reichler \& Mooi, 2005; Mooi, Martínez \& del Río, 2016).

In the present paper, we provide a supplementary description to the original one of Brisaster iheringi (de Loriol, 1902), a nomenclatural combination previously mentioned by Parma (2012) but without any justification.

The specimens come from a locality that yields a rather exceptional echinoderm diversity, including sand dollars (Mooi, Martínez 
\& del Río, 2016), ophiuroids (Caviglia, Martínez \& del Río, 2007; Martínez, del Río \& Pérez, 2010), sea stars (Martínez \& del Río, 2015), ichnofossils made by spatangoids (Buatois, Bromley, Mángano, Bellosi \& Carmona, 2003; Carmona, Buatois, Mángano \& Bromley, 2008), cassiduloids (unpublished), and with the addition of Brisaster iheringi, heart urchins. Most of the precedent authors incidentally made reference to or even figured these heart urchins, since they are easily seen in the outcrop, but they were never described until now.

Abbreviatures: CIRGEO-Pi: Invertebrate Paleontological Collection of the Centro de Investigaciones en Recursos Geológicos, Argentina (presently housed at MACN); CPBA: Cátedra de Paleontología, Facultad de Ciencias Exactas, Físicas y Naturales, Universidad de Buenos Aires; MACN-Pi: Invertebrate Paleontological Collection of the Museo Argentino de Ciencias Naturales "Bernardino Rivadavia"; MHNG GEPI: Muséum d'histoire naturelle, Genéve; PRI: Paleontological Research Institution, Ithaca, USA.

\section{GEOLOGICAL SETTING AND TAPHONOMY}

Fossiliferous horizons yielding the material analyzed are located at the base of the exposures of the Chenque Formation Bellosi, 1990, located two kilometers south of Punta Maqueda in the San Jorge Basin (northeastern Santa Cruz Province) (46 2'7.49'S - 67³6'8.78”W, Fig. 1). At its type locality in the surroundings of the Comodoro Rivadavia City, this unit consists of a 500 meters thick siliciclastic and pyroclastic sedimentary sequence, composed of five shallowing upwards parasequences (Bellosi, 1995). The lowermost Parasequences I and II are highly tuffaceous and characterized by several fossiliferous beds that contain a rich molluscan fauna that belongs to the Jorgechlamys julianaReticulochlamys borjasiensis Assemblage (del Río, 2004), of Early Miocene age.

The studied section at Punta Maqueda corresponds to Parasequence I and consists of 12 $\mathrm{m}$ thick sandstones, deposited in a shoreface environment according to the interpretation of Buatois, Bromley, Mángano, Bellosi \& Carmona (2003). Basal beds of this section are only visible during low tides, and are composed of up to $4.5 \mathrm{~m}$ thick bioturbated grey-greenish fine sandstones, deposited in a distal lower shoreface environment affected by weak storms. Overlying this bed there are $5 \mathrm{~m}$ thick fine-medium sandstones intercalated with shell-beds from the middle shoreface, capped by $3 \mathrm{~m}$ thick upper shoreface, cross-stratified medium sandstones.

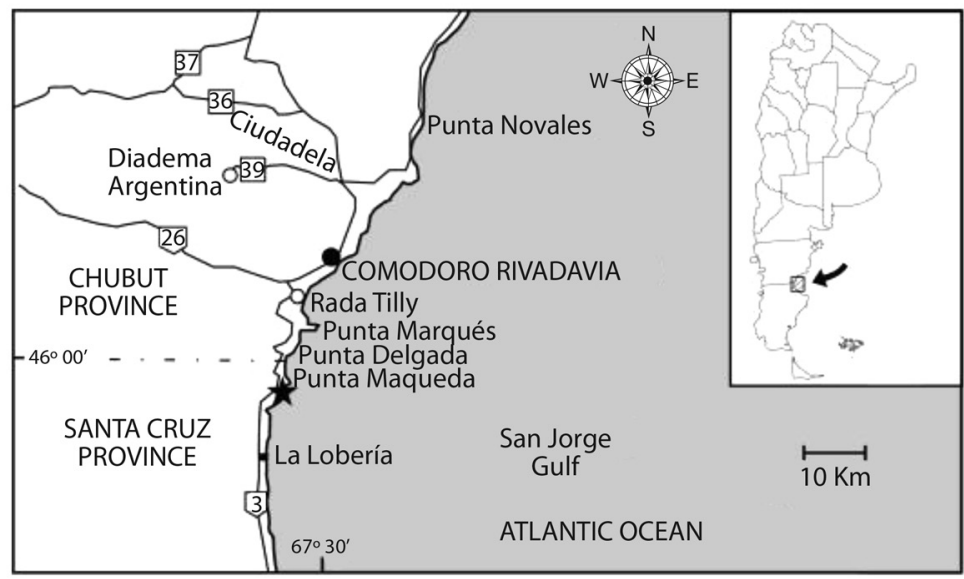

Fig. 1. Geographic location of the studied outcrop (star).

Fig. 1. Localización geográfica del afloramiento estudiado (estrella). 
Seven fossiliferous beds are recognized, among which five represent thin autochthonous assemblages composed by monospecific aggregations, and two (M1 and M4 in Fig. 2) correspond to polyspecific ones. Brisaster iheringi comes from the lowest bed (M1, Fig. 2), which yields a rather high echinoderm diversity, being associated to sand dollars (Mooi, Martínez \& del Río, 2016), ophiuroids (Caviglia, Martínez \& del Río, 2007; Martínez, del Río \& Pérez, 2010), sea stars (Martínez \& del Río, 2015), cassiduloids (unpublished), and to bunches of oysters, clusters of the pinnid bivalve Atrina sp. (a species with a very fragile shell) and octocorals, each species constituting isolated patches in life position. This bed also records ichnofossils made by spatangoids (Buatois, Bromley, Mángano, Bellosi \& Carmona, 2003; Carmona, Buatois, Mángano \& Bromley, 2008).

The specimens are in life position (Fig. 3) and several ones preserve the spines covering the ambulacra (e.g. Fig. 4 A). In spite of this undisturbed position and overall good preservation, the test is very thin and weakened by the present-day tidal regime, alternating wet and dry conditions. In fact, the test is supported by the infilling sediment and breaks very easily. As a result, the exemplars are very fragile and it is difficult to collect them in good condition and to clean them properly.

\section{TAXONOMY}

Suprageneric classification follows Kroh and Smith (2009).

Order Spatangoida Claus, 1876

Suborder Paleopneustina

Markov \& Solovjev, 2001

Family Schizasteridae Lambert in

Doncieux, 1905

Genus Brisaster Gray, 1855

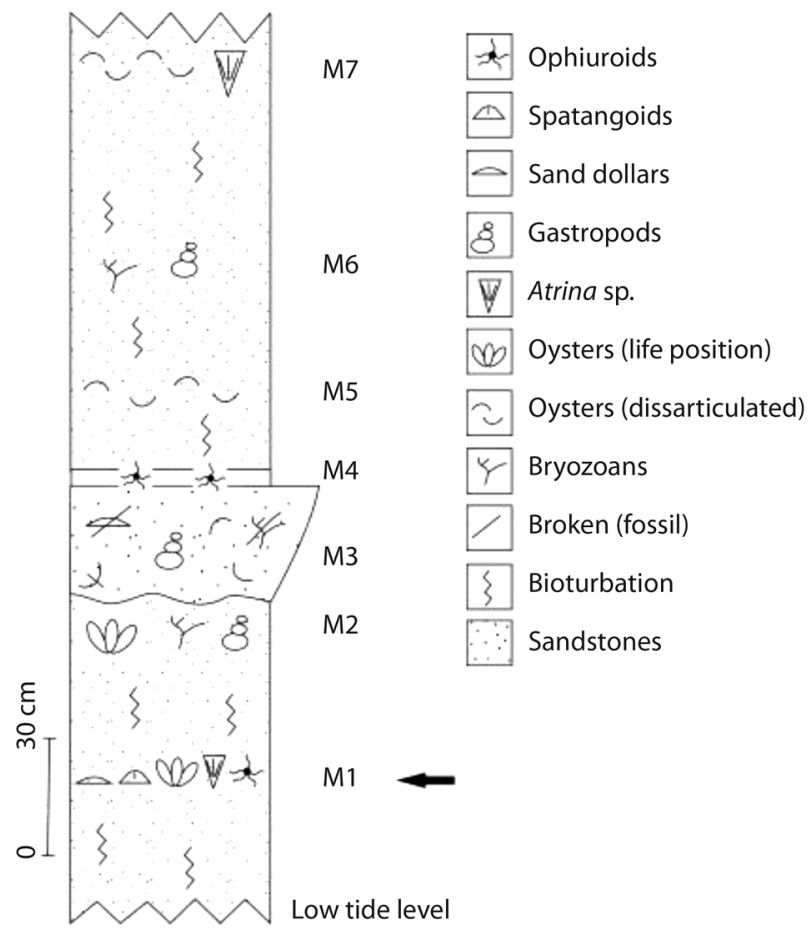

Fig. 2. Stratigraphic section of the studied outcrop. The arrow indicates the bed with Brisaster iheringi.

Fig. 2. Sección estatigráfica del afloramiento estudiado. La flecha indica el nivel con Brisaster iheringi. 


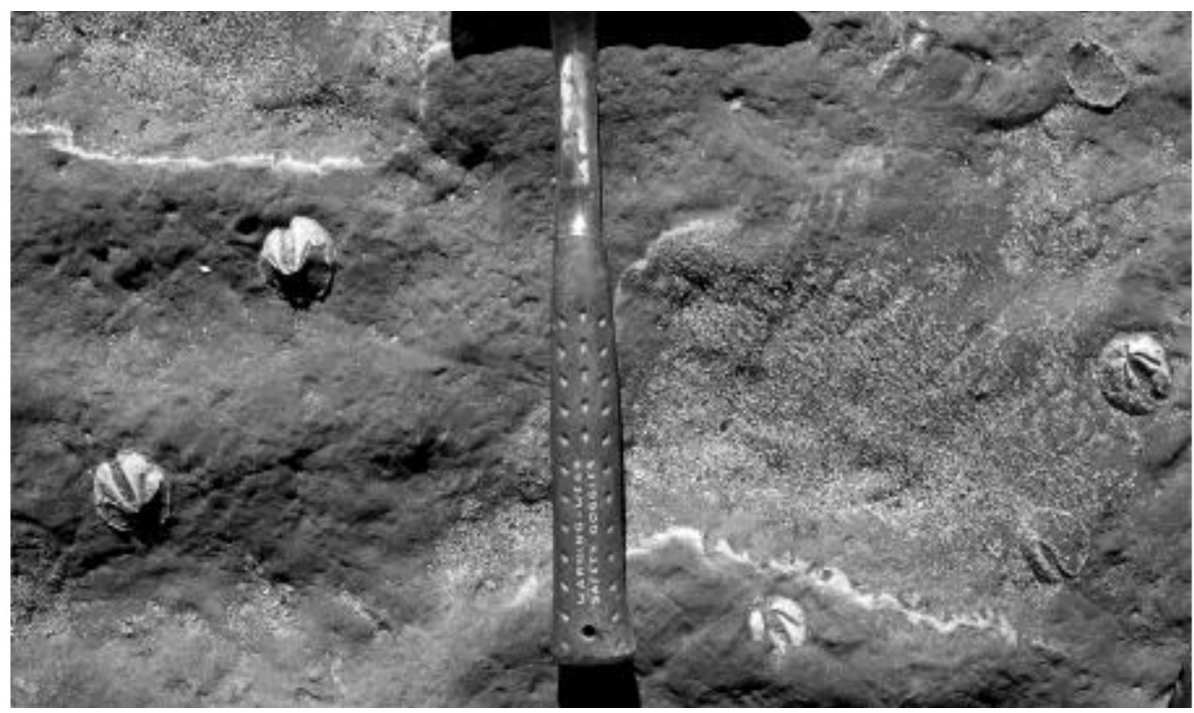

Fig. 3. B. iheringi in life position. Photograph taken at low tide.

Fig. 3. $B$. iheringi en posición de vida. Foto tomada en baja marea.

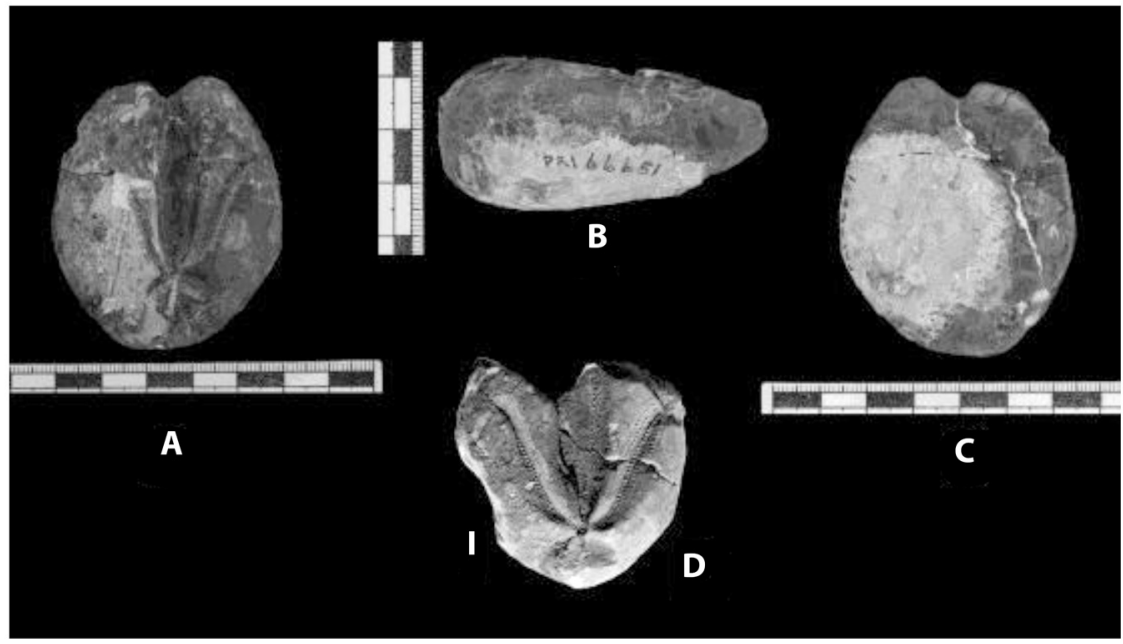

Fig. 4. (A-B-C) PRI 66651, dorsal, right lateral, and ventral sides. Courtesy of the Paleontological Research Institution, Ithaca, New York. (D). MHNG GEPI 28012, dorsal side. Courtesy of the Muséum d'histoire naturelle, Genéve. scale bar: $10 \mathrm{~mm}$.

Fig. 4. (A-B-C). PRI 66651, lados dorsal, lateral derecho y ventral. Cortesía del Paleontological Research Institution, Ithaca, New York. (D). MHNG GEPI 28012, vista doral. Cortesía del Muséum d'histoire naturelle, Genéve. escala: $10 \mathrm{~mm}$. 
Type species: Brissus fragilis Duben \& Koren, 1846, p. 280; by original designation. Recent, North Atlantic Ocean.

\section{Brisaster iheringi (de Loriol, 1902)}

Figs. 3-7

1897. Schizaster ameghinoi Ihering: Ortmann, p. 62 (partim), Pl. XIII, Fig. 1a.

1902. Schizaster iheringi de Loriol, p. 21, Pl. II, Fig. 2.

1959. Schizaster iheringi de Loriol: Bernasconi, p. 171, Pl. III, Fig. 6.

2012. Brisaster iheringi: Parma, p. 417, 419

Type material: Although we can infer that de Loriol (1902) based his description on a single specimen (following the description he says (p. 22): 'J'ai revue d' autres exemplaires du Sc. Ameghinoi..."), he did not designate a holotype among the exemplars mentioned in the text. The figured specimen would be MHNG GEPI 28012 (fig. 4 D), housed in the Collection de Loriol, Museum de Genéve, but unfortunately it is currently an internal mold, and it cannot be established a clear identity with the published drawing. Moreover, its locality (Golfo San Jorge) does not coincide with the indicated in the legend of the figure (Bajo San Julián). Another candidate is MACN-Pi 4524, since Bernasconi (1959) indicates that it was determined by de Loriol, and in the Ameghino collection of the Museo Argentino de Ciencias Naturales there are other echinoderms figured by this author. Besides, the locality mentioned in de Loriol (1902) and in the label coincides. Finally, the dimensions indicated by this author and Bernasconi (1959) are nearly the same. The specimen is lost.

A third exemplar is mentioned by de Loriol (1902), which was in these times in Ihering's hands. Therefore, it is surely not the figured one.

In addition, de Loriol (1902) includes in the new species the exemplar figured in Ortmann (1902: pl. 13, fig. 1a). This specimen is housed now in the Paleontological
Research Institution under the number 66651 (Fig. 4, A-C).

Original description (de Loriol, 1902: 21): "Dimensions. longueur $50 \mathrm{~mm}$, Largeur, par rapport à la longueur 0.96. Test très déprimé, presque aussi large que long, rétréci et profondément echancré en avant, tronqué sur le bord postérieur. Face supérieure faiblement relevée dans l'aire interainbulacraire impaire. Appareil apical très excentrique en arrière. Aire ambulacraire antérieure impaire dans un sillon extrêmement large, pas très creusé, tout a fait plat sur le fond, nullement rétréci vers le pourtour, qu' il échancre profondément; les zones porifères, tout a fait rectilignes, ont 48 paires de pores très petits. Ambulacres antérieurs pairs très longs, larges, faiblement creusés et un peu flexueux; ils divergent très graduellement et demeurent, relativement, rapprochés du sillon antérieur; les zones porifères sont larges et comptent 40 paires de pores; j'ai pu les compter sur un autre exemplaire dans lequel les ambulacres pairs sont complets, mais dont la forme est très altérée, l'aire interporifère a presque la largeur de l'une des zones porifères. Ambulacres postérieurs très divergents, extrêmement courts, ovales, peu profonds, avec douze ou quinze paires de pores seulement dans chaque zone porifère. Périprocte au sommet de la face postérieure, non recouvert par un rostre. Péristome inconnu."

Supplementary description (based in specimens shown in Figs. 5 and 6): Test medium sized (maximum length $=75 \mathrm{~mm}$ ), cordiform, widest at the middle but nearly equal in maximum length and width, with a sulcus indenting the anterior margin and slender posterior margin. Posterior face truncated, inclined towards the apex. In profile, the test is somewhat depressed, highest posterior to apical disc, at the posterior carina. Apical disc ethmolytic with three gonopores (gonopore absent in genital plate 2, the madreporite), very posterior to the center (at $68-75 \%$ of test length). Petals sunken, well developed, anterior petals 2.5-4 times longer than posterior ones; 


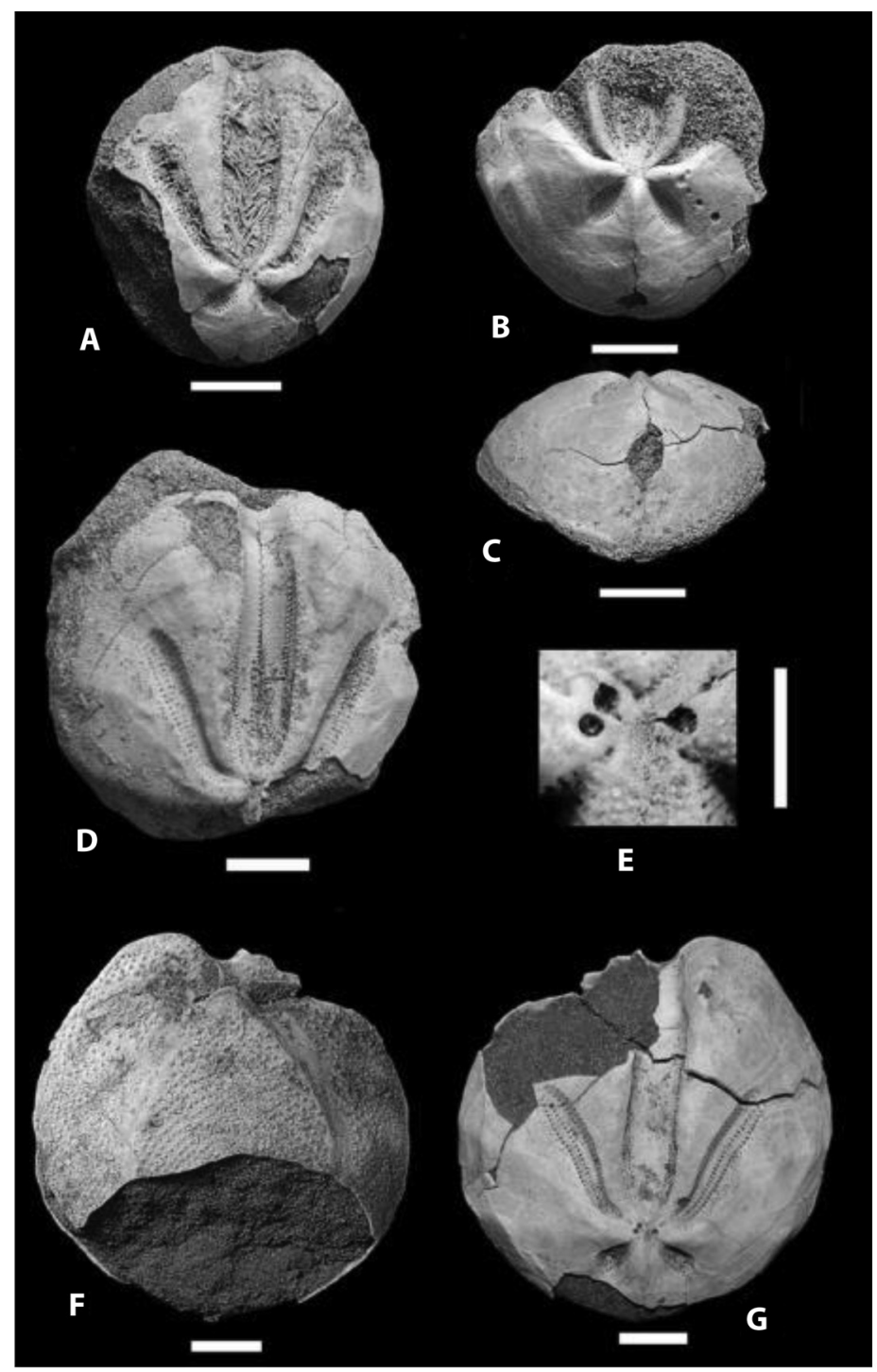

Fig. 5. (A) MACN-Pi 6228, dorsal side, scale bar: $10 \mathrm{~mm}$; (B-C) MACN-Pi 6229, dorsal and posterior sides, scale bars: 10 mm; (D) MACN-Pi 6227, dorsal side, scale bar: 10 mm; (E-G) MACN-Pi 6226, (E) apical system, scale bar: 5 mm; (F-G) ventral and dorsal views, scale bars: $10 \mathrm{~mm}$.

Fig. 5. (A) MACN-Pi 6228, vista dorsal, escalar: $10 \mathrm{~mm}$; (B-C) MACN-Pi 6229, vistas dorsal y posterior, escala: $10 \mathrm{~mm}$; (D) MHNG GEPI 28012, vista dorsal. Cortesía del the Muséum d'histoire naturelle, Genéve. escala 10 mm; (E-G) MACNPi 6226, (E) sistema apical, escala: $5 \mathrm{~mm}$; (F-G) vistas ventral y dorsal, escala: $10 \mathrm{~mm}$.

petal pores well developed, oval, of nearequal size. Anterior petals diverge at around $70-80^{\circ}$, posterior ones at around $90-100^{\circ}$. The anterior pair is much longer than the posterior one and flexed proximally and (in less extent) distally. Interporiferous zones of the paired petals nearly equal in width to the poriferous zones. Anterior ambulacrum wide and deeply sunken from apex, with vertical walls, 44 pores at test length $53 \mathrm{~mm}, 40$ pores at test length $45 \mathrm{~mm}$. Pore-pairs well developed, pores of each pair separated by protuberance; interporiferous zone much wider than the poriferous zone (ca. four times). Petals with 40 (anterior) 


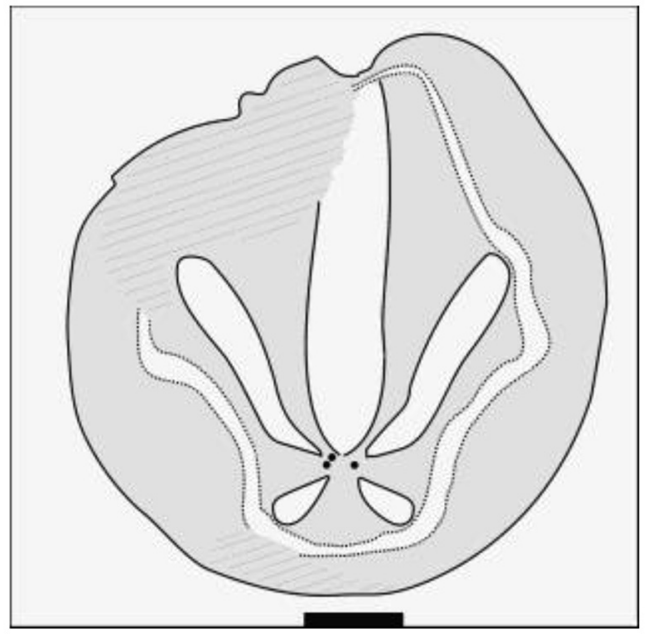

Fig. 6. MACN-Pi 6226, sketch of dorsal view showing the trajectory of the fasciole, scale bar: $10 \mathrm{~mm}$.

Fig. 6. MACN-Pi 6226, esquema de la vista dorsal mostrando la trayectoria de la fasciola, escala: $10 \mathrm{~mm}$.

and 12 (posterior) pore pairs at test length 53 $\mathrm{mm}, 36$ and 11 respectively at test length 34 $\mathrm{mm}$. Peripetalous fasciole indented between anterior and posterior petals. Peristome anterior, broader than long; labral plate with thin rim, projecting over peristome, longitudinally elongate, widened posteriorly and very anteriorly at rim (mushroom-shaped). Plastron amphisternous. Periproct oval, longer than wide, visible from above, situated in upper half of inclined posterior face.

Dimensions (mm):

$\begin{array}{lccc}\text { specimen } & \text { length } & \text { width } & \text { height } \\ \text { MACN-Pi 6226 } & 53 & 51 & - \\ \text { MACN-Pi 6227 } & 45 & - & - \\ \text { MACN-Pi 6228 } & 34 & 32 & - \\ \text { MACN-Pi 6229 } & - & 34 & 18\end{array}$

Material: MACN-Pi 6226-6229, two kilometers south of Punta Maqueda, Santa Cruz Province, Chenque Formation, Early Miocene.

Remarks: The ethmolytic apical system with three gonopores situates this species in Brisaster and not in Schizaster (with four gonopores). According to Smith \& Kroh (2011),
Brisaster is known from the Late Cretaceous to the Recent, and its species cover a wide range of depths (40 to $1300 \mathrm{~m}$ ) and regions.

de Loriol (1902: 22) mentioned two localities: "Bajo de San Julian, Pan d'Azucar.Patagonien moyen", and "Golfo de St.- Jorge.- Patagonien inférieur"; and figured the specimen from San Julián (see legend of pl. II, fig. 2). We believe that the latter specimen was housed at the Museo Argentino de Ciencias Naturales "B. Rivadavia" (MACNPi 4524) and it is presently lost. Bernasconi (1959) had the opportunity to study it and provided a brief description, pointing that it consisted in an internal mold. Apart from it, Bernasconi (op. cit.) also mentioned other specimen from a well in Comodoro Rivadavia (original number CPBA 2681, new and present number CPBA 6477, Figs. 7A-B) that would fit into $B$. iheringi, but since some diagnostic characters are lacking or not visible, its assignment to this species is doubtful. Besides, unfortunately there is no data about the depth and sedimentology of the sample, and it is not possible to establish its stratigraphic origin.

A third exemplar of Schizaster iheringi reported by Bernasconi (1959) from the Danian sedimentites at Bajo del Gualicho (Río Negro Province) was later included into Proraster atavus (Arnaud in Cotteau, 1883) by Parma \& Casadío (2005). The inspection of this specimen, (CPBA 6478) led us to agree with those authors.

More recently, two further papers mentioned the doubtful presence of Schizaster or Brisaster in the Paleogene-Neogene exposures of western Patagonia. Chiesa, Parma \& Camacho (1995: 63, Pl- VI, fig 10) assigned to the genus Brisaster twelve specimens from El Bajo (=Estancia Argentina, El Chacay Formation), an Early Miocene unit according to Parras et al. (2008) and Cuitiño et al. (2015). They considered these fossils similar to Schizaster iheringi, but decided to leave the taxonomic identification at the generic level. In our opinion, at least the figured specimen (CPBA 17352, Fig. 5C) can be assigned to $B$. iheringi. 


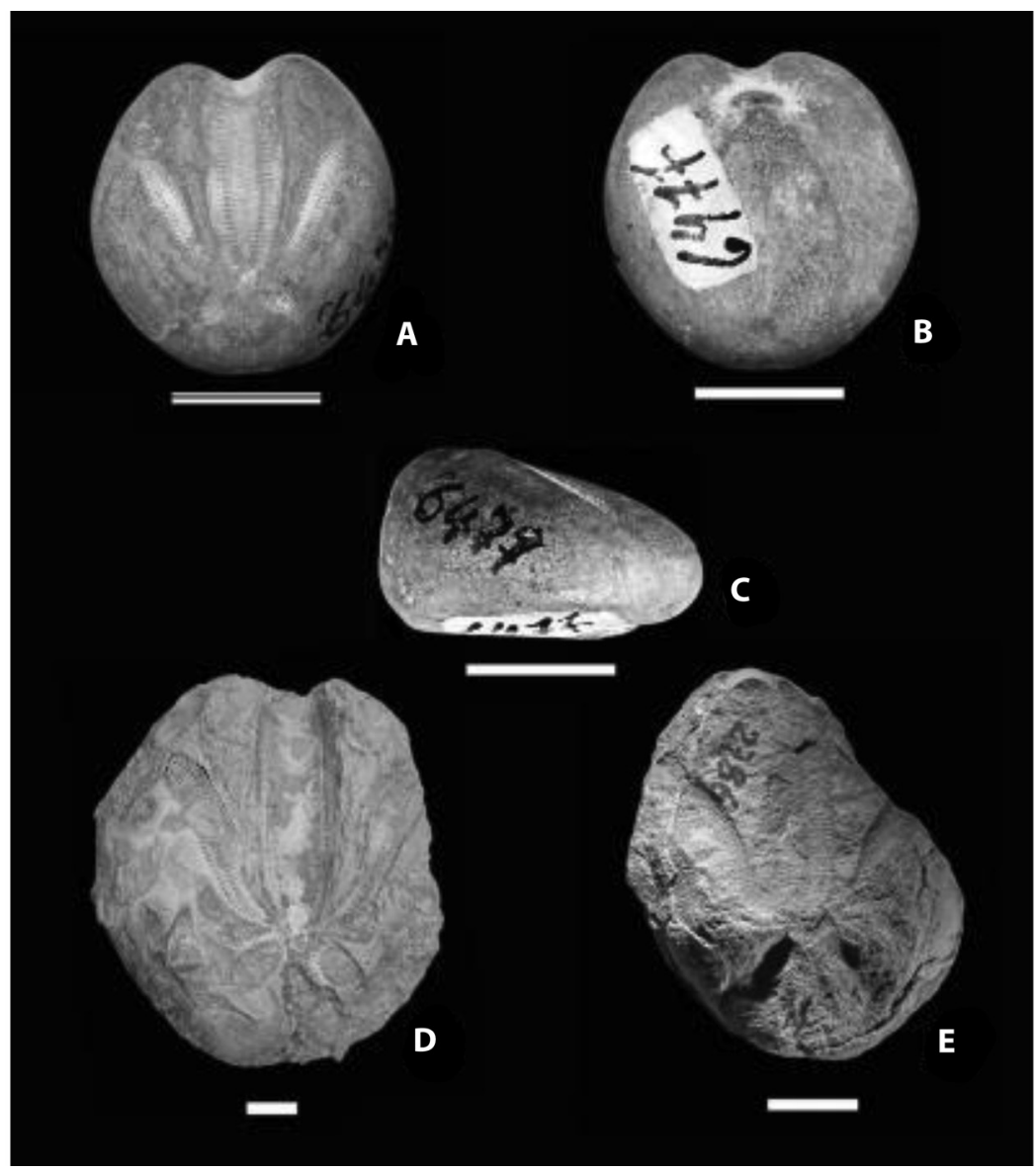

Fig. 7. (A-B-C) CPBA 6477, dorsal, ventral and right lateral sides; (D) CPBA 17352, dorsal side; (E) CIRGEO-Pi 2786, dorsal side. Scale bars: $10 \mathrm{~mm}$. Photographs A-C kindly provided by Marian Tanuz, Universidad de Buenos Aires.

Fig. 7. (A-B-C) CPBA 6477, vistas dorsal, ventral y lateral derecha; (D) CPBA 17352, vista dorsal; (E) CIRGEO-Pi 2786, vista dorsal. Escala: $10 \mathrm{~mm}$. Fotos A-C provistas gentilmente por Marian Tanuz, Universidad de Buenos Aires.

The other paper corresponds to Chiesa \& Camacho (2001), who included Brisaster sp. in Table 2 (p. 303), but in the taxonomical section (p. 312, this part acknowledged to Graciela Parma) it is introduced as Schizaster? sp. In the discussion section, the authors(s?) mentioned that the specimen could be attributed to Brisaster, but due to the bad preservation they preferred to be conservative and considered it as Schizaster? sp. The exemplar (CIRGEO-Pi 2786, Fig. 7D) is now housed in the MACN-Pi collection, and effectively the preservation is bad precluding a reliable taxonomic determination.
Finally, some authors mentioned the presence of spatangoids in the study area, but it is not clear if they collected specimens, and they did not provide any description. In this sense, Carmona et al. (2008: fig. 7.3), in the context of an ichnofossils analysis, illustrated spatangoids that seems to be nearly identical to $B$. iheringi, from Playa Las Cuevas, just a few kilometers to the north to our fossiliferous site; and Parma (2012) incidentally mentioned $B$. ihering $i$ as coming from the San Jorge Gulf but without specifying any locality.

According to the information discussed above, the stratigraphic range of the genus 
Brisaster in Patagonia must be restricted to the Early Miocene.

\section{ACKNOWLEDGMENTS}

We are very grateful to Collection Managers Marian Tanuz (Universidad de Buenos Aires), Lionel Calvin (Muséum d'histoire naturelle, Genéve) and Leslie L. Skibinski (Paleontological Research Institution) for kindly providing information and photos of specimens under their care. The reviewers Andreas Kroh and James Nebelsick made valuable comments and suggestions that improved the paper.

\section{RESUMEN}

Descripción suplementaria de Brisaster iheringi (Spatangoida: Schizasteridae) del Mioceno de la Patagonia Argentina. Los equinoides argentinos son importantes como herramientas bioestratigráficas. Nuevos ejemplares de Schizaster iheringi (de Loriol, 1902) provenientes de la Formación Chenque (Mioceno Temprano, Patagonia, Argentina) permiten agregar detalles a su descripción original, en especial de su sistema apical y cara ventral. La especie es incluida en el género Brisaster, siendo la primera referencia incuestionable documentada de este género para el Neógeno de Argentina. Asimismo, se evalúan todos los especímenes asignados a esta especie reportados anteriormente, concluyendo que la presencia de Brisaster en Patagonia se restringe al Mioceno Temprano.

Palabras clave: Argentina; Mioceno; Fm. Chenque; Spatangoida; Brisaster.

\section{REFERENCES}

Bellosi, E. (1990). Formación Chenque: registro de la transgresión patagoniana (Terciario medio) de la cuenca de San Jorge, Argentina. Actas $11^{\circ}$ Congreso Geológico Argentino, San Juan, 2, 57-60.

Bellosi, E. (1995). Paleogeografía y cambios ambientales de la Patagonia central durante el Terciario Medio. Boletin de Informaciones Petroleras, 44, 50-83.

Bellosi, E. \& Barreda, V. D. (1993). Secuencias y palinología del Terciario Medio en la Cuenca San Jorge, registro de oscilaciones eustáticas en Patagonia. $12^{\circ}$ Congreso Geológico Argentino y $2^{\circ}$ Congreso de Exploraciones de Hidrocarburos, 1, 78-86.

Bernasconi, I. (1959). Equinoideos fósiles de la colección del Museo Argentino de Ciencias Naturales. Physis, 21(61), 137-176.
Buatois, L. A., Bromley, R. G., Mángano, M. G., Bellosi, E. \& Carmona, N. (2003). Ichnology of shallow marine deposits in the Miocene Chenque Formation of Patagonia: complex ecologic structure and niche partitioning in Neogene ecosystem. Asociación Paleontológica Argentina, Publicación Especial, 9, 85-95.

Carmona, N. B., Buatois, L. A., Mángano, M. G. \& Bromley, R. G. (2008). Ichnology of the Lower Miocene Chenque Formation, Patagonia, Argentina: animal - substrate interactions and the Modern Evolutionary Fauna. Ameghiniana 45, 93-122.

Caviglia, S. E., Martínez, S. \& del Río, C. J. (2007). A new Early Miocene species of Ophiocrossota (Ophiuroidea) from Southern Patagonia, Argentina. Neues Jahrbuch für Geologie und Paläontologie, $245,147-152$.

Chiesa, J. O. \& Camacho, H. H. (2001). Invertebrados marinos eocenos de la parte inferior de la Formación Río Foyel, provincia de Río Negro, Argentina. Revista Española de Paleontología 16: 299-316.

Chiesa, J. O., Parma, S. G. \& Camacho, H. H. (1995). Invertebrados marinos de la Formación El Chacay (Eoceno), Provincia de Santa Cruz, Argentina. Sistemáca y bioestratigrafía. Academia Nacional de Ciencias Exactas, Físicas y Naturales. Monografías, 11, 17-68.

Cuitiño, J. I., Scasso, R. A., Ventura Santos, R. \& Mancini, R. H. (2015). Sr ages for the Chenque Formation in the Comodoro Rivadavia región (Golfo San Jorge basin, Argentina): stratigraphic implications. Latin American Journal of Sedimentology and Basin Analysis, 22, 3-12.

De Loriol, P. (1902). Notes pour servir a l'étude des échinodermes (2) 1.52 pp. 3 pl.

Del Río, C. J. (2004). Tertiary Marine molluscan assemblages of Eastern Patagonia (Argentina): a biostratigraphic analysis. Journal of Paleontology, 78, 1097-1122.

Del Río, C. J., Martínez, S., Stilwell, J. D. \& Concheyro, A. G. (2007). Paleontology of the Danian Cerros Bayos section (La Pampa Province, Argentina). Alcheringa, 31, 241-269.

Kroh, A. \& Smith, A. B. (2009). The phylogeny and classification of post-Palaeozoic echinoids. Journal of Systematic Palaeontology, 8, 147-212.

Kroh, A., Mooi, R., del Río C. J. \& Neumann, C. (2013). A new late Cenozoic species of Abertella (Echinoidea: Clypeasteroida) from Patagonia. Zootaxa, 3608, 369-378.

Martínez, S. (1984). Amplaster coloniensis n.g n.sp. (Echinoidea: Monophorasteridae) del Mioceno de Uruguay. Memorias del III Congreso Latinoamericano de Paleontología, México, 505-508. 
Martínez, S. \& del Río, C. J. (2015). Fossil Asterozoa (Echinodermata) of Argentina. Revista de Biologia Tropical/International Journal of Tropical Biology, 43 (Suppl. 2), 1-6.

Martínez, S. \& Mooi, R. (2005). Extinct and extant sand dollars (Clypeasteroida: Echinoidea) from Uruguay. Revista de Biología Tropical/International Journal of Tropical Biology), 53 (Suppl. 3), 1-7.

Martínez, S., Reichler, V. \&. Mooi, R. (2005). A new species of Abertella (Echinoidea: Scutellina) from the Gran Bajo del Gualicho Formation (Late Early Miocene - Early Middle Miocene), Río Negro Province, Argentina. Journal of Paleontology, 79, 1229-1233.

Martínez, S., del Río, C. J. \& Pérez, D. (2010). A brittle star bed from the Miocene of Patagonia, Argentina. Lethaia, 43, 1-9.

Martínez, S., del Río, C. J. \& Concheyro, A. (2011). Danian (Early Paleocene) echinoids from the Roca Formation, northern Patagonia, Argentina. Neues Jahrbuch für Paläontologie und Geologie, 261, 165-176.

Mooi, R., Martínez, S. \& Parma, S. G. (2000). Phylogenetic Systematics of Tertiary Monophorasterid sand dollars (Clypeasteroida: Echinoidea) from South America. Journal of Paleontology, 74, 263-281.
Mooi, R., Martínez, S. \& del Río, C. J. (2016). A new South American Miocene species of 'one-holed' sand dollar (Echinoidea: Clypeasteroida: Monophorasteridae). Zootaxa, 4173, 45-54.

Ortmann, A. (1902). Tertiary Invertebrates. Reports of the Princeton Uniersity Expedition to Patagonia, 4, 2: 45-332, 28 pl., Princeton NJ. \& Stuttgart.

Parma, S. G. (2012). El género Brissopsis L. Agassiz, 1840 (Echinoidea: Spatangoida) en el Paleógeno y Neógeno de la República Argentina Revue de Paléobiologie, Vol. spéc., 11, 417-427.

Parma, S. G. \& Casadío, S. (2005). Upper CretaceousPaleocene echinoids from northern Patagonia, Argentina. Journal of Paleontology, 79, 1072-1087.

Parras, A., Griffin, M., Feldmann, R., Casdío, S., Schweitzer, C. \& Marenssi, S. (2008). Correlation of marine beds based on Sr- and Ar-date determinations and faunal affinities across the Paleogeone/Neogene boundary in southern Patagonia, Argentina. Journal of South American Earth Sciences, 26, 204-216.

Smith, A. B. \& Kroh, A. (ed.) (2011). The Echinoid Directory. World Wide Web electronic publication. (http:// www.nhm.ac.uk/research-curation/projects/echinoiddirectory, accessed 10/12/16). 